Отже, аналіз наукової літератури дозволяє нам говорити, що в Україні практично не проводилися дослідження, присвячені проблемі зближення двох найважливіших сфер сучасного суспільства - освіті й науки, особливо в контексті підготовки майбутніх учителів. Крім того, недостатньо робіт, в яких розкриваються питання організації наукової діяльності в університеті, при якій відбувається максимальне впровадження наукової діяльності в навчальний процес на всіх його етапах. Спільний науковий й навчальний потенціал вищої школи недостатньо використовується для підготовки майбутніх учителів. Механізмів інтеграції науково-дослідної й навчальної роботи, що реально діють у сучасних умовах, поки що не створено.

Перспективу подальшої наукової роботи ми бачимо в обгрунтуванні й розробленні педагогічної системи інтеграції науково-дослідної й навчальної роботи в університетській підготовці майбутніх учителів.

1. Глущенко А. А. Влияние интеграции учебной и научной деятельности преподавателей высшей школы на качество подготовки специалиста : дисс. ... доктора пед. наук : 13.00.01 / Глущенко Александр Алексеевич. - М., 1998. - 431 с. 2. Сазонова 3. С. Интеграция образования, науки и производства как методологическое обоснование подготовки современного инженера : дисс. ... доктора пед. наук : 13.00.01 / Сазонова Зоя Сергеевна. - Казань, 2008. - 439 с. 3. Якушева С. Д. Университетский образовательный округ - интеграция науки, образования и практики : [монография] / С. Д. Якушева. - М. : АПКиППРО, 2009. - 200 с. 4. Супян В. Б. Исследовательские университеты США: механизм интеграции науки и образования : монография / В. Б. Супян. - М. : Магистр, 2009. - 339 с. 5. Микитюк О. М. Теорія і практика організації науково-дослідної роботи у вищих закладах освіти України в XIX ст. : дис. ... д-ра пед. наук : 13.00.01 / Микитюк Олександр Миколайович. - Х., 2003. - 405 с. б. Гнізділова О. А. Становлення i розвиток наукових шкіл у вищих педагогічних навчальних закладах Східної України в XX столітті : дис. ... д-ра пед. наук : 13.00 .01 / Гнізділова Олена Анатоліївна. - Х., 2012. - 499 с. 7. Князян М. О. Система формування самостійно-дослідницької діяльності майбутніх учителів іноземних мов у процесі ступеневої підготовки : автореф. дис. на здобуття наук. ступеня доктора пед. наук : спец. 13.00.04 «Теорія і методика професійної освіти» / М. О. Князян. - Одеса, 2007. 45 с. 8. Луценко І. В. Формування дослідницької культури майбутніх учителів у діяльності студентського наукового товариства : дис. ... канд. пед. наук : 13.00 .04 / Луценко Ірина Володимирівна. - Луганськ, 2011. - 212 с. 9. Тихенко Л. В. Формування творчих здібностей старшокласників у процесі дослідницької діяльності в Малій академії наук України. : дис. ... канд. наук : 13.00.07 / Тихенко Лариса Володимирівна. - Полтава, 2009. - 199 с.

УДК 372.878

Л. М. Ракімянська, кандидат пед. наук, доиент, Криворізький педагогічний інститут ДВНЗ «Криворізький начіональний університет»

\title{
НАУКОВО-ПЕДАГОГІЧНА ДУМКА ПРО МОРАЛЬНО-ЕСТЕТИЧНЕ ВИХОВАННЯ ЗАСОБАМИ МУЗИЧНОГО МИСТЕЦТВА
}

Ракітянська Л. М. Науково-педагогічна думка про морально-естетичне виховання засобами музичного мистецтва.

У статті проаналізовано погляди сучасних науковців на проблему взаємозв'язку морального та естетичного у філософських та психолого-педагогічних дослідженнях.

Ключові слова: моральне, естетичне, морально-естетичне виховання.

Ракитянская Л. Н. Научно-педагогическая мысль о морально-естетичес-ком воспитании средствами музыкального искусства.

В статье анализируются научные взгляды современных ученых на проблему взаимосвязи морального и эстетического в философских и психолого-педагогических исследованиях.

Ключевые слова: моральное, эстетическое, морально-эстетическое воспитание. 
Rakityanskaya L. N. Scientific and pedagogical thought about the relationship of moral and aesthetic. The article analyzes the scientific and pedagogical views of philosophers and educators to the problem of the relationship of moral and aesthetic and the role of musical art in the moral and aesthetic education.

Key words: moral, aesthetic, the moral and aesthetic education.

Ідея досягнення гармонії між властивими людській природі сутнісними моральними та естетичними якостями активно розроблялася протягом багатовікового розвитку філософсько-педагогічної думки.

Першу відому форму вираження зв'язку етичного та естетичного знаходимо у давній міфології, яка містить елементи релігії, філософії, мистецтва в органічній єдності, відображаючи неділимість релігійно-міфологічного мислення первісних людей.

Як педагогічна проблема, вирішення якої сприяло б цілісному і гармонійному розвитку особистості, формування духовно-моральної краси людини вперше була сформульована мислителями Давньої Греції.

У сучасних умовах проблема морально-естетичного виховання особистості розглядається як складова загальної гуманістично-демократичної концепції суспільного перетворення. Вона займає одне 3 центральних місць у дослідженнях вітчизняних науковців.

Mema cmammi - проаналізувати погляди дослідників на проблему взаємозв'язку морального та естетичного, ролі музичного мистецтва в морально-естетичному вихованні.

Аналіз наукової літератури з окресленої проблеми дозволяє стверджувати, що вона $\epsilon$ предметом наукового аналізу філософських, психолого-педагогічних досліджень. Специфіка предмету кожної з наук румовлює особливості підходів до її розв'язання.

Теоретико-методологічні основи взаємозв'язку морального та естетичного знайшли всебічне обгрунтування в сучасній філософії. Науковці-філософи (І. Зязюн, О. Канарський, В. Кудін, Л. Левчук, О. Фортова) вказують на зв'язок морального та естетичного як об'єктивну закономірність, що має місце в житті й мистецтві. Духовні якості людини (ідейні, моральні, естетичні) функціонують в органічній єдності, реалізуються в іманентній характеристиці людської цілісності. Дослідники стверджують, що діалектика розвитку єдності морального та естетичного відображає рівні усвідомлення людиною своєї суспільної сутності, рівні іiї духовного саморозвитку у формах людської чуттєвої діяльності [5, с. 50]. У характері моральних та естетичних почуттів, що утворюють емоційно-почуттєву сферу особистості, міститься те загальне, що складає органічний взаємозв'язок між моральними та естетичними якостями людини, які реалізуються у процесі її розвитку.

За визначенням О. Фортової, моральні та естетичні почуття - це такі переживання людиною свого ставлення до дійсності, основою якого $є$ здатність «ставитись», «відноситися», що виявляється в почутті [5, с. 145].

На органічний взаємозв'язок естетичних та моральних почуттів вказує i В. Кудін. Науковець наголошує на тому, що в морально-естетичних почуттях акумулюються відповідні оцінки добра і зла, порядності та нечесності, моральності та аморальності. Крізь їх призму відбувається сприймання суспільних цінностей, формується ставлення людини до певних чинників життя. Людська почуттєва діяльність виявляє себе у формах небайдужості, співпереживання, співчуття, співстраждання.

Визначення категоріального статусу поняття «небайдужість» здійснюється як в естетичних, так і етичних дослідженнях. В естетичній теорії О. Канарського поняття «небайдужість» розглядається як «логічне начало» дослідження людської почуттєвої діяльності [3]. Таку ж думку висловлює і О. Фортова, підкреслюючи, що «небайдужість», як здатність людини «відноситися», виявляється у чуттєвій формі. Вона не є властивістю власне естетичного, а відображає у своїй специфіці сутність, що характеризує людську чуттєву діяльність загалом, у єдності морального та естетичного [5, с. 63]. Небайдужість 
виступає началом почуттєвої діяльності людини і відображає ставлення людини до навколишньої дійсності в єдності моральних та естетичних почуттів.

Однією з форм вияву людських почуттів $є$ співпереживання, яке, за ствердженням О. Фортової, $є$ не лише специфічною особливістю естетичного сприймання. Необхідною умовою співпереживання є спілкування людини з іншими людьми, а це становить сферу морального. Тому співпереживання, як форма людської чуттєвості, не є властивістю естетичного чи етичного, вона відображає саме внутрішню єдність моральних та естетичних переживань. Здатність людини ставити себе на місце іншої людини, сприймати і розуміти іiі почуття як свої власні, визначається у філософії поняттям «співстраждання», яке характеризує ставлення людини до іншої як вищу міру небайдужості. Саме ця здатність людини робить іï причетною до всього людства, спонукає до перетворення дійсності.

Отже, поняття «небайдужість», «співпереживання», «співстраждання» відображають механізм функціонування почуттєвої сфери людини.

У дослідженнях І. Зязюна розкривається зміст поняття «естетичний досвід» [2], який автор розуміє як духовне утворення, що існує і виявляє себе через «людські чуттєві сили». Естетичний досвід $є$ основою естетичного ставлення людини до суспільства, забезпечує максимальний розвиток ії спеціальних здібностей, перетворює результати виховання в особистісні норми і настанови. Акумулюючи в собі досвід суспільних відносин, що склався як стійкі ціннісні орієнтації, естетичний досвід $\epsilon$ своєрідною програмою поведінки і діяльності людини. Засвоєні естетичні норми становлять внутрішнє надбання людини, яке визначає її вимоги до себе і до навколишнього світу.

Естетичне ставлення людини до дійсності, краса людської поведінки тісно пов’язані, на думку I. Зязюна, з етичним ставленням людини до навколишньої дійсності. Тому науковець вважає і доказово обгрунтовує в своїх працях, що «естетична чуттєвість як узагальнений вираз естетичного досвіду, виникає, існує і розвивається в діалектичній єдності з моральним досвідом».

Розкриваючи сутність людської чуттєвої діяльності, науковці-філософи підкреслюють вплив мистецтва на емоційно-моральний, духовний розвиток людини. Унікальна здатність мистецтва стикатися з усіма аспектами духовного світу людини дозволяє йому активно залучати кожного до втіленого емоційно-чуттєвого досвіду, накопиченого багатьма поколіннями. Естетичний, а через нього й етичний вплив мистецтва на духовність людини сприяє збагаченню індивідуального досвіду переживань, формуванню особистого ставлення до сприйнятого у вигляді співпереживання. Мистецтво спонукає до співпереживання, формує досвід людських відносин, сприяє взаєморозумінню між людьми. Мистецтво, як унікальний засіб розвитку духовності людини, водночас спонукає iii до дій. Щоб те ідеальне, що несе в собі мистецтво, людина перетворювала в наявні форми людських відносин і людської життєдіяльності загалом. Цю думку особливо підкреслює в своїх працях О. Канарський. Саме в такій «післядії», уважає дослідник, справжнє призначення і моральна сила мистецтва [3].

У психолого-педагогічних дослідженнях моральне та естетичне виховання розглядаються як відносно самостійні складники єдиного цілісного процесу виховання особистості. Науковці-педагоги (С. Горбенко, Л. Коваль, Р. Любима, О. Олексюк, С. Петуніна, С. Хлєбик, А. Щербо) підкреслюють, що взаємозв'язок цих напрямків виховання не механічний, а органічний, зумовлений єдністю духовної сутності людини. Серед чинників, які впливають на морально-естетичний розвиток особистості, психологопедагогічна наука винятково важливого значення надає мистецтву, його гуманістичній природі.

Л. Коваль підкреслює особливий взаємозв'язок музики з суспільними ідеалами, загальнолюдськими цінностями, із способами взаєморозуміння між людьми, які відображають співпричетність композитора, виконавця, слухача до життя суспільства і викликають співпереживання, співучасть за допомогою специфічних виражальних 
засобів. До таких автор відносить не лише традиційні виражальні засоби, але й увесь виховний потенціал музики, що відображає взаємодію вчителя з учнями у складних процесах сприйняття, усвідомлення, освоєння музичного мистецтва і формування на цій основі багатства морально-естетичних відносин [4].

Педагог-дослідник С. Горбенко [1], вивчаючи проблему морально-естетичного виховання підлітків засобами народної пісенної творчості, експериментально перевірив і довів у своєму дослідженні, що у процесі усвідомлення й емоційного засвоєння кращих зразків фольклору з'являються реальні можливості розвитку дітей з високими естетичними i моральними якостями, які знаходять свій вияв у співчутті, співпереживанні, повазі до оспіваних героїв. Перевіряючи визначені педагогічні умови ефективного моральноестетичного виховання школярів засобами народної пісенної творчості, науковець приходить до висновку, що морально-естетичне виховання школярів під час роботи над народною піснею може бути більш ефективним, якщо його проводити у взаємозв'язку урочної і позаурочної роботи, зіставляючи при цьому виконавські варіанти народної пісні, застосовуючи колективне обговорення iіi морально-естетичного змісту, намагаючись виробити в дітей вміння ідентифікувати себе із зображеними у творі подіями, порівнювати із сучасним життям.

У дослідженні С. Хлєбик розкривається зміст морально-естетичного досвіду молодших школярів, який визначається як процес оволодіння художньо-естетичними та моральними знаннями в спілкуванні 3 художніми творами, набуття умінь та навичок емоційного реагування та осмисленого сприйняття морально-естетичного змісту явищ мистецтва й дійсності. Результатом сформованості морально-естетичного досвіду школярів $\epsilon$ активізація діяльності самосвідомості і розвиток на цій основі інтегративних якостей особистості - співпереживання, співчуття, співтворчості, які проявляються у гуманістичній спрямованості відносин людини [6].

Стислий огляд поглядів наковців на проблему взаємозв'язку морального та естетичного, ролі музичного мистецтва в морально-естетичному вихованні переконує у складності проблеми і необхідності визначення та дослідження спеціальних педагогічних умов, за яких цей процес буде ефективним.

\section{Література}

1. Горбенко С. С. Морально-естетична спрямованість у вивченні пісенного матеріалу на уроці музики / С. С. Горбенко// Мистецтво у школі: зб. статей [упоряд. І. М. Гадалова]. - К. : Обрій, 1996. - С. 30 - 32. 2. Зязюн І. А. Соціокультурне проектування естетичного досвіду / І. А. Зязюн // Естетичний досвід вчителя. - Херсон, 1997. - С.20-23. 3. Канарский А. С. Природа искусства и активность его эстетического воздействия на человека/ А. С. Канарский // Вопросы философии. 1991. - № 2 - С. 15-19. 4. Коваль Л. Г. Виховання почуття прекрасного/ Лариса Григорівна Коваль. - К. : Рад. школа, 1983. - 120 с. 5. Фортова А. И. О диалектическом единстве нравственного и эстетического: [монография] / Александра Ивановна Фортова. - К. : Высшая школа, 1985. - 150 с. 6. Хлебик С. Р. Формирование нравственно - эстетического опыта младших школьников средствами искусства / С. Р. Хлебик // Искусство в школе. - 2001. - № 3. - С. 15-17.

УДК 372: 37. 035

I. П. Рогальська, доктор пед. наук, професор, Уманський державний педагогічний університет імені Павла Тичини

\section{ВЗАЄМОДІЯ СІМ'Ї ТА ОСВІТНЬОЇ УСТАНОВИ В СОЦАЛІЗАЦЇ̈ ОСОБИСТОСТІ В ДИТИНСТВІ}

Рогальська І. П. Взаємодія сім'ї та освітньої установи у соціалізації особистості в дитинстві.

У статті автор звертається до висвітлення особливостей взаємодії сім'ї та освітньої установи у соціалізації особистості в дитинстві з позиції іiі специфіки у сучасних умовах соціальної нестабільності, зокрема через обгрунтування дошкільної установи як відкритої соціально- 